\title{
Hubungan antara Kehamilan Remaja dan Riwayat Pemberian ASI Dengan Kejadian Stunting pada Balita di Wilayah Kerja Puskesmas Pujon Kabupaten Malang
}

\section{The Correlation Between Adolescent Pregnancy, Breastfeeeding Practice and Stunted Children at Puskesmas Pujon Kabupaten Malang}

\author{
Dwi Agista Larasati* ${ }^{*}$ Triska Susila Nindya ${ }^{1}$, Yuni Sufyanti Arief ${ }^{2}$
}

\begin{abstract}
ABSTRAK
Latar Belakang: Stunting adalah kejadian gagal tumbuh yang sering terjadi pada anak. Prevalensi stunting di Indonesia sendiri masih tinggi. Tingginya jumlah anak yang mengalami stunting merupakan hasil dari tingginya faktor yang memengaruhinya seperti; pernikahan dini yang menyebabkan terjadinya kehamilan pada remaja dan pemberian ASI yang tidak eksklusif.

Tujuan: Menganalisis apakah terdapat hubungan antara kehamilan remaja dan riwayat pemberian ASI eksklusif terhadap kejadian stunting pada balita.

Metode: Penelitian ini merupakan penelitian analitik, menggunakan metode case - control. Jumlah sampel dalam penelitian ini adalah 58 anak, yang dipilih menggunakan metode multiple stage sampling dan dibagi menjadi dua kelompok yaitu stunting dan non - stunting. Data yang dikumpulkan meliputi pengukuran panjang badan anak dan kuisioner riwayat pemberian ASI eksklusif, kuisoner usia ibu pertama kali hamil dan identitas responden. Analisis data menggunakan software SPSS dengan uji Chi - square untuk menganalisis hubungan variabel dependen dengan independen sedangkan software WHO Antro digunakan untuk menganalisis status gizi balita (TB/U) menurut $z-$ score.

Hasil: Hasil dari penelitian ini menunjukan hubungan yang signifikan antara kehamilan remaja dengan kejadian stunting pada balita $(p=0,016)$ dengan nilai Odds - ratio adalah 3,86 . Di samping itu juga ditemukan hubungan yang signifikan antara pemberian ASI non - eksklusif dengan kejadian stunting pada balita $(p=0,00)$ dengan nilai Odds - ratio adalah 3,23 . Semakin muda usia ibu mengalami kehamilan dan anak tidak diberikan ASI eksklusif maka akan semakin besar risiko anak mengalami stunting.
\end{abstract}

Kesimpulan: Penelitian ini menyimpulkan bahwa kehamilan remaja dan pemberian ASI non - eksklusif dapat meningkatkan risiko anak mengalami stunting.

Kata Kunci: stunting, kehamilan remaja (adolescent pregnancy), ASI eksklusif

\section{ABSTRACT}

Background: Stunting is growth failure which commonly occurs among children. In Indonesia, the prevalence of stunted growth is still high. The high number of stunted children is a result of the risk factors, which are early marriage that causes adolescent pregnancy, and non-exclusive breastfeeding. Objectives: To analyze the relationship between teenage pregnancy and a history of exclusive breastfeeding against the incidence of stunting in infants under five years.

Method: This research was a descriptive analysis which used case-control method. The samples in this research were 58 children, who were selected using multiple stage sampling, and divided into two groups; stunting and non-stunting. The collected data include the children's height measurement and 
questionnaire of exclusive breastfeeding history, as well as questionnaire of mother's age at first pregnancy and the respondents' identity. The data were analyzed using SPSS software with chi square test and WHO Anthro

Results: The results of this research revealed significant correlation between adolescent pregnancy and stunted children $(p=0.016)$, with odds ratio of 3.86. Moreover, significant correlation was also manifested between non-exclusive breastfeeding and stunted children ( $p=0.003)$, with odds ratio of 3.23. The younger the mother at pregnancy and the absence of exclusive breastfeeding resulted in higher risk of child stunting. Therefore, this research concluded that adolescent pregnancy and nonexclusive breastfeeding might increase the risk of child stunting.

Conclusion: This research concluded that adolescent pregnancy and non - exsclusive breastfeeding might increase the risk of stunting in children.

Keywords: stunting, adolescent pregnancy, exsclusive breastfeeding

\author{
*Koresponden: \\ larassasmi@gmail.com \\ ${ }^{1}$ Departemen Gizi Kesehatan, Fakultas Kesehatan Masyarakat, Universitas Airlangga \\ ${ }^{2}$ Fakultas Keperawatan, Universitas Airlangga
}

\section{PENDAHULUAN}

Stunting merupakan salah satu gangguan pertumbuhan yang seringkali terjadi pada anak. Prevalensi anak stunting di dunia mengalami penurunan antara tahun 1990 hingga 2004 yaitu sebanyak 39,6\% menjadi $23,8 \%$. Persentase ini dalam angka mengalami penurunan dari 255 juta menjadi 159 juta balita. Asia merupakan daerah dengan penurunan jumlah anak stunting paling besar. Penurunan persentase balita stunting $47,6 \%$ menurun menjadi $25,1 \%$. Sekalipun terjadi penurunan nilai stunting yang cukup besar, namun persentase ini secara global masih tinggi yaitu sebesar $25,1 \%$ dari jumlah keseluruhan populasi anak di dunia ${ }^{1}$. Prevalensi balita stunting sendiri pada negara berkembang paling tinggi berada pada kelompok usia $6-24$ bulan $^{2}$

Di Indonesia prevalensi balita stunting (pendek dan sangat pendek) menurut Riskesdas tahun 2013 adalah 37,2\% jika dibandingkan dengan tahun 2010 (35,6\%) dan tahun 2007 (36,8\%) tidak menunjukan penurunan atau perbaikan yang signifikan. Diukur menggunakan indikator tinggi badan menurut umur (TB/U) di Provinsi Jawa Timur pada tahun 2015 presentase balita stunting adalah $31 \%$ dan mengalami penurunan menjadi $27 \%$ pada tahun berikutnya jauh di bawah presentase nasional yaitu $37 \%^{3}$.
Presentase stunting pada balita di wilayah kerja Puskesmas Pujon Kabupaten Malang sendiri pada tahun 2017 mencapai 42,8\%, dengan kategori sangat pendek adalah 9,5\% dan pendek/stunted mencapai nilai $33,3 \%{ }^{4}$. Nilai stunting balita di wilayah kerja Puskesmas Pujon Kabupaten Malang yang sangat tinggi bahkan melebihi prevalensi global dan nasional menjadi masalah gizi serius yang harus mendapat perhatian lebih.

Stunting merupakan gangguan pertumbuhan linier yang disebabkan adanya malnutrisi asupan zat gizi kronis yang berulang yang ditunjukan dengan nilai $z$ - score tinggi badan menurut usia $(\mathrm{TB} / \mathrm{U})<-2 \mathrm{SD}$ berdasarkan standart WHO. Masalah balita pendek (stunting) menggambarkan adanya masalah gizi kronis, dipengaruhi dari kondisi ibu atau calon ibu, masa janin, masa bayi atau balita, termasuk penyakit yang diderita selama masa balita. Seperti masalah gizi lainnya, tidak hanya terkait masalah kesehatan namun juga dipengaruhi oleh berbagai kondisi lain yang secara tidak langsung memengaruhi kesehatan ${ }^{1}$.

Menurut framework WHO yang diterbitkan pada tahun 2013 menyebutkan bahwa terdapat beberapa penyebab terjadinya stunting pada balita. Penyebab yang pertama adalah faktor ibu dan lingkungan sekitar rumah. Faktor ibu (maternal factor) meliputi gizi yang buruk saat pra-konsepsi, kehamilan 
dini, kesehatan mental ibu, kelahiran premature, IUGR (Intra Uterine Growt Restriction), jarak kelahiran yang pendek dan hipertensi. Faktor yang kedua adalah pemberian ASI yang kemudian dijabarkan menjadi inisiasi menyusui dini yang terlambat, ASI non - eksklusif, dan penyapihan yang terlalu cepat ${ }^{1}$.

Seperti yang telah dijelaskan pada paragraph sebelumnya bahwa salah satu penyebab terjadinya stunting pada balita adalah kehamilan dini. Di Indonesia prevalensi pernikahan di usia dini cukup tinggi. Menurut hasil Susenas tahun 2012 - 2013 persentase wanita umur 10 tahun ke atas yang pernah melakukan perkawinan di daerah pedesaan mencapai angka 37,79\% di tahun 2012 dan $37,71 \%$ di tahun 2013. Prevalensi perkawinan dini di provinsi Jawa Timur sendiri pada tahun 2013 juga cukup tinggi yaitu berada di posisi ke dua setelah provinsi Jawa Barat dengan prevalensi mencapai $42,77 \%$ (pada usia $16-18$ tahun). Prevalensi perkawinan dengan usia mempelai < 20 tahun di Kabupaten Malang pada tahun 2013 mencapai 33,02\% dan pada tahun 2014 mencapai 31,43\% ${ }^{5}$. Cakupan ASI eksklusif di provinsi Jawa Timur tahun 2015 sebesar 68,8\%, angka tersebut menurun dibandingkan dengan tahun 2014 yaitu $72,89 \%^{3}$. Pemberian ASI secara eksklusif sendiri di Kabupaten Malang mencapai $57,90 \%$ dan mengalami peningkatan menjadi $64,71 \%$ pada tahun 2013 dan meningkat lagi pada tahun 2014 menjadi 66,61\% ${ }^{6}$. Sekalipun mengalami peningkatan, presentase cakupan ASI eksklusif ini masih jauh dari target nasional.

Tingginya angka pernikah dini di Indonesia menyebabkan kehamilan pertama juga terjadi di usia dini atau saat ibu masih remaja dan sering disebut kehamilan remaja. Usia ibu ketika pertama kali hamil sangat berpengaruh terhadap jalannya kehamilan. Usia ideal seorang wanita untuk melahirkan adalah $20-25$ tahun. Jika usia ibu lebih muda atau lebih tua dari usia tersebut maka akan lebih berisiko mengalami komplikasi kehamilan. Seorang wanita yang hamil pada usia remaja akan mendapat early prenatal care lebih sedikit. Faktor ini yang diprediksi menyebabkan bayi lahir dengan berat rendah (BBLR) serta kematian pada bayi. Kematian bayi, bayi premature dan bayi lahir dengan berat badan rendah akan tinggi pada pasangan remaja, usia laki - laki dan perempuan sama berpengaruhnya terhadap hal ini. Sebagian besar remaja putri yang hamil memiliki IMT (Indeks Massa Tubuh) dengan kategori underweight. Hal ini disebabkan oleh kurangnya asupan gizi dikarenakan kekhawatiran pada bentuk tubuh selama masa remaja dan kurangnya pendidikan tentang gizi. Kedua hal tersebut kemudian menjadi sebab rendahnya kenaikan berat badan ibu selama masa kehamilan. Kenaikan berat badan yang tidak sesuai inilah yang kemudian berakibat pada kenaikan jumlah bayi lahir premature yang menjadi salah satu faktor terjadinya stunting pada balita ${ }^{7}$.

Faktor lain terjadinya stunting pada balita adalah pemberian ASI eksklusif yang sangat berpengaruh terhadap status gizi anak usia 0 sampai dengan 24 bulan. Ditemukan bahwa $16 \%$ wanita yang memberikan ASI eksklusif pada anak mereka kurang dari enam bulan, 38,1\% diantaranya mengalami stunting dan mengalami underweight ${ }^{8}$. Bayi dengan usia kurang dari enam bulan yang diberikan ASI eksklusif ternyata memiliki panjang tubuh, berat badan lebih baik dan cenderung tidak menampakan tanda - tanda stunting dibandingkan dengan anak yan diberikan ASI non - eksklusif. Perbedaan nilai signifikansi terhadap indikator Length for Age (LAZ) sebesar 0,5 antara bayi yang diberikan ASI eksklusif dan bayi yang diberikan ASI non eksklusif. Pengenalan atau pemberian cairan lain selain ASI sebelum usia empat bulan dikaitkan dengan peningkatan resiko penyakit gastrointestinal. Peningkatan resiko penyakit inilah yang kemudian dapat menyebabkan growth retardation, kekurangan mikronutrien dan dalam jangka waktu panjang akan meningkatkan resiko mengalami penyakit penyakit infeksi lain selama dua tahun awal kehidupan ${ }^{9}$. Penelitian sejenis sering dilakukan di Indonesia maupun dunia untuk mengetahui hubungan kehamilan remaja dengan kejadian stunting pada balita, namun penelitian penelitian tersebut biasanya dilakukan pada balita dengan rentang usia 6 - 59 bulan, tidak banyak penelitian yang spesifik pada rentang usia baduta (bawah dua tahun) padahal masalah gizi seringkali terjadi saat $1000 \mathrm{HPK}$ pada balita. Di samping itu di wilayah kerja 
Puskesmas Pujon Kabupaten Malang sendiri belum pernah terdapat penelitian yang serupa.

Penelitian ini mengambil fokus pada kejadian stunting pada baduta usia $12-24$ bulan dengan rumusan masalah apakah terdapat hubungan antara kehamilan di usia remaja dan riwayat pemberian ASI eksklusif dengan kejadian stunting pada balita. Tujuan dari penelitian ini adalah menganalisis apakah terdapat hubungan antara kehamilan remaja dan riwayat pemberian ASI eksklusif terhadap kejadian stunting pada balita di wilayah kerja Puskesmas Pujon Kabupaten Malang. Pentingnya penelitian ini adalah dapat digunakan sebagai bahan tambahan kajian tentang permasalahan gizi pada balita. Bahwa masalah stunting pada balita dipengaruhi oleh beberapa aspek baik aspek spesifik maupun aspek sensitive, sehingga penelitian ini dapat menjadi pertimbangan dalam penyusunan program dan atau kebijakan mengenai upaya penurunan prevalensi stunting di Indonesia.

\section{METODE}

Penelitian yang dilakukan ini merupakan penelitian analitik dengan desain penelitian case control. Istilah case dan control menunjukan bahwa, setiap kasus yaitu panjang badan balita pendek dan atau sangat pendek, yang dicarikan kontrolnya yaitu panjang badan balita normal. Penelitian ini menggunakan data primer yaitu data yang dikumpulkan sendiri oleh peneliti melalui pengukuran panjang badan. Di samping itu penelitian ini juga menggunakan data sekunder dari Puskesmas Pujon Kabupaten Malang untuk mengetahui prevalensi kejadian stunting dan tidak stunting pada masing - masing wilayah desa. Data ini hanya digunakan sebagai acuan pemilihan wilayah yang digunakan sebagai wilayah penelitian (pengambilan sampel).

Populasi dalam penelitian ini adalah semua baduta di wilayah kerja Puskesmas Pujon Kabupaten Malang. Sampel penelitian diambil dengan metode multiple stage sampling. Pertama metode ini dilakukan dengan cara purposive sampling dalam memilih desa dengan prevalensi stunting paling rendah dan paling tinggi. Populasi balita stunting yang mengikuti skrining berjumlah 273 balita dan balita non - stunting berjumlah
153 balita. angka ini adalah jumlah keseluruhan balita bukan baduta karena Puskesmas tidak memiliki data jumlah baduta stunting dan non - stunting. Pemilihan sampel sebanyak 29 baduta dilakukan dengan cara simple random sampling sehingga semua baduta memiliki kesempatan yang sama menjadi sampel penelitian. Baduta yang masuk dalam kelompok kasus adalah baduta yang memiliki panjang badan menurut usia $(\mathrm{PB} / \mathrm{U})<-2 \mathrm{SD}$ sedangkan baduta non - stunting adalah baduta yang memiliki panjang badan menurut usia $(\mathrm{PB} / \mathrm{U}) \geq-2 \mathrm{SD}$.

Kriteria inklusi sampel yang digunakan adalah balita yang memiliki buku KIA atau memiliki catatan pertumbuhan lain yang relevan seperti catatan yang diberikan oleh bidan atau petugas kesehatan setempat sebagai pengganti buku KIA. Sampel penelitian dihitung menggunakan rumus besar sampel uji hipotesis dan proporsi (Lemeshow et.,al,1990) dan diperoleh jumlah 29 balita pada masing masing kelompok dengan kriteria inklusi yang telah disebutkan. Variabel perantara yang ditanyakan pada ibu adalah tingkat pendidikan dan pekerjaan sebelum menikah. Tingkat pendidikan ibu dikelompokan menjadi dua yaitu pendidikan rendah dan pendidikan tinggi. Pendidikan rendah dimulai dari tidak bersekolah, sekolah dasar dan sekolah menengah sedangkan pendidikan tinggi dimulai dari sekolah menengah atas, diploma dan sarjana. Pekerjaan ibu sebelum menikah hanya dikelompokan menjadi bekerja dan tidak bekerja. Variabel bebas dalam penelitian ini adalah usia ibu pertama hamil dan riwayat pemberian ASI. Usia ibu pertama hamil didapat menggunakan kuisioner dan ditanyakan langsung kepada ibu, sedangkan riwayat pemberian ASI ditanyakan menggunakan kuisioner Infant Young Children Feeding Practice (IYCF) dan World Health Organization (WHO) tahun 2010. Variabel terikat pada penelitian ini adalah status gizi baduta yaitu panjang badan menurut usia $(\mathrm{PB} / \mathrm{U})$ yang diukur menggunakan pengukur panjang badan baduta (length board) dengan tingkat ketelitian $0.1 \mathrm{~cm} / 1 \mathrm{~mm}$ dan mikrotoa. Cara pengumpulan data usia ibu pertama hamil dan riwayat pemberian ASI ditanyakan langsung pada responden sedangkan panjang badan bayi diukur langsung pada responden baduta. 
Penelitian ini menggunakan analisis univariat dengan tujuan untuk menganalisis deskripif variabel penelitian. Analisis univariat digunakan untuk mengestimasi parameter populasi yaitu karakteristik ibu diantaranya yaitu usia yang dikategorikan menjadi kehamilan remaja ( $\leq 19$ tahun) dan hamil usia normal (> 19 tahun); status riwayat pemberian ASI yang dibagi menjadi ASI eksklusif dan ASI non - eksklusif. Selain itu, status gizi balita yaitu panjang badan dikelompokan menjadi stunting $(<-2 \mathrm{SD})$ dan tidak stunting $(\geq-2 \mathrm{SD})$, status gizi ini dianalisis ini menggunakan software WHO Antro. Analisis bivariate digunakan untuk mengeatahui besarnya faktor risiko usia ibu pertama hamil dan riwayat pemberian ASI terhadap panjang badan balita dengan menggunakan Odds ratio. Untuk mengetahui hubungan antara usia ibu pertama hamil dan riwayat pemberian ASI dengan panjang badan balita menggunakan uji Chi square. Uji statistic ini menggunakan software computer SPSS 21.

\section{HASIL DAN PEMBAHASAN}

Karakteristik ibu yang diteliti dalam penelitian ini adalah tingkat pendidikan dan status bekerja sebelum ibu menikah. Kedua karakteristik ini dianggap menjadi faktor terkuat pengambilan keputusan untuk menikah. Rendahnya tingkat pendidikan dan tidak adanya pekerjaan sebelum menikah di pihak perempuan selalu dikaitkan dengan tingkat ekonomi yang rendah yang mengakibatkan pernikahan terjadi pada usia muda (asumsi penulis). Pada penelitian ini didapatkan bahwa status pendidikan ibu yang memiliki pendidikan rendah pada kelompok balita kasus (balita stunting) sejumlah 22 orang atau mencapai $75,8 \%$ sedangkan pendidikan tinggi sejumlah 7 orang atau mencapai $24,2 \%$. Pada kelompok balita kontrol (balita non stunting) ibu yang memiliki latar belakang pendidikan rendah adalah 16 orang atau mencapai $55,2 \%$ sedangkan pendidikan tinggi mencapai 13 orang atau 44,8\%. Pekerjaan responden yang diidentifikasi merupakan status bekerja responden sebelum menikah. Identifikasi ini hanya sebatas pada responden memiliki pekerjaan atau tidak sebelum menikah, tanpa melihat apa jenis pekerjaan responden. Pertanyaan mengenai pekerjaan ibu sebelum menikah ini ditanyakan untuk mengetahui apakah status bekerja pada ibu memengaruhi keputusan untuk menikah di usia dini atat tidak. Pada penelitian ini didapatkan bahwa ibu yang tidak bekerja sebelum menikah pada kelompok kasus (balita stunting) sejumlah 17 orang atau mencapai $58,7 \%$ sedangkan yang bekerja berjumlah 12 orang atau $41,3 \%$. Pada kelompok balita kontrol (balita non - stunting) ibu yang tidak bekerja sejumlah 15 orang atau mencapai $51,7 \%$ sedangkan ibu yang bekerja sejumlah 14 orang atau mencapai $48,3 \%$. Pada tabel 1 dapat diketahui bahwa ibu pada kelompok balita kasus yang memiliki pendidikan rendah lebih besar dibandingkan dengan kelompok balita kontrol. Hal ini sejalan dengan pekerjaan ibu sebelum menikah, bahwa ibu pada kelompok balita kasus yang tidak memiliki pekerjaan sebelum menikah lebih besar dibandingkan dengan kelompok balita kontrol.

Tingkat ekonomi keluarga akan berpengaruh terhadap tingkat pendidikan anggota keluarga. Rendahnya pendapatan ekonomi keluarga akan memaksa si anak untuk putus sekolah dan tidak melanjutkan pendidikan ke jenjang yang lebih tinggi lagi. Tinggi rendahnya usia kawin pertama berhubungan dengan tinggi rendahnya akses kepada pendidikan ${ }^{10}$. Tingkat pendidikan maupun pengetahuan anak yang rendah akan mengakibatkan adanya kecenderungan melakukan pernikahan di usia dini ${ }^{11}$. Tidak adanya pekerjaan pada responden selalu dikaitkan dengan keadaan ekonomi yang rendah. Anggota keluarga dewasa yang tidak bekerja dianggap sebagai beban ekonomi keluarga sehingga pernikahan merupakan salah satu jalan untuk membantu perekonomian keluarga. Dalam hal ini keluarga memiliki hambatan dalam memenuhi kebutuhan anaknya yaitu kebutuhan yang diperlukan setelah semua kebutuhan primer 
Tabel 1. Karakteristik Ibu Balita

\begin{tabular}{lcccc}
\hline Variabel & \multicolumn{2}{c}{ Kasus } & \multicolumn{2}{c}{ Kontrol } \\
\cline { 2 - 5 } & $\begin{array}{c}\text { Frekuensi } \\
\text { (n) }\end{array}$ & $\begin{array}{c}\text { Presentase } \\
\text { (\%) }\end{array}$ & $\begin{array}{c}\text { Frekuensi } \\
\text { (n) }\end{array}$ & $\begin{array}{c}\text { Presentase } \\
\text { (\%) }\end{array}$ \\
\hline $\begin{array}{c}\text { Pendidikan } \\
\text { Rendah }\end{array}$ & 22 & & & \\
Tinggi & 7 & 75,8 & 16 & 55,2 \\
\hline Status Bekerja & & 24,2 & 13 & 44,8 \\
$\quad$ Tidak bekerja & 17 & 58,7 & & \\
$\quad$ Bekerja & 12 & 41,3 & 15 & 51,7 \\
\hline
\end{tabular}

terpenuhi ${ }^{12}$. Di daerah pedesaan persentase pernikahan remaja wanita mencapai $26,8 \%$ lebih tinggi dibandingkan dengan daerah perkotaan yang hanya mencapai $20,5 \%$. Perbedaan persentase ini juga terjadi antara remaja yang mendapatkan pendidikan baik dengan remaja yang tidak mendapatkan pendidikan dengan baik. Pada remaja yang menyelesaikan pendidikan hingga ke jenjang sekolah menengah pertama pernikahan remaja mencapai $44,6 \%$ sedangkan pada kelompok remaja yang menempuh pendidikan lebih tinggi hanya mencapai $15,5 \%$. Keadaan ekonomi juga berdampak terhadap kejadian pernikahan di usia dini, di mana anak yang memiliki latar belakang ekonomi rendah, kejadian pernikahan dini lebih tinggi dibandingkan dengan anak yang memiliki latar belakang ekonomi mampu ${ }^{13}$.

Dari tabel 2 dapat diketahui bahwa ibu yang hamil di usia remaja atau usia dini ( $\leq 19$ tahun) pada kelompok balita kasus (balita stunting) lebih tinggi jika dibandingkan dengan ibu pada kelompok balita kontrol (balita non stunting). Pada kelompok balita kasus (balita stunting) ibu yang hamil pada usia dini atau usia remaja sejumlah 13 orang atau mencapai $41,4 \%$ sedangkan yang hamil pada usia normal sejumlah 16 orang atau mencapai 58,6\%.

Pada kelompok balita kontrol (balita non - stunting) ibu yang hamil di usia dini atau usia remaja sejumlah 7 orang atau mencapai $20,7 \%$. Rata - rata usia kehamilan pertama pada kedua kelompok ibu balita adalah $20 \pm 0,34$ dengan usia paling muda mengalami kehamilan pertama adalah usia 14 tahun dan usia paling tua adalah 26 tahun. Pada tabel 2 ini dapat dilihat bahwa jumlah ibu pada kelompok balita kasus yang hamil pada usia remaja lebih besar dibandingkan dengan ibu pada kelompok balita kontrol.

Hasil analisis Chi - square menyatakan bahwa terdapat hubungan yang signifikan antara kehamilan dini dengan kejadian stunting pada balita dengan nilai $p-$ value $=$ $0,016(p<0,05)$. Pada interval kepercayaan (Cl) $95 \%$, nilai Odds Ratio (OR) yang dihitung $(3,86)$. Nilai Odds Ratio menunjukan bahwa balita yang lahir dari ibu yang hamil pada usia remaja beresiko 3,86 lebih besar mengalami stunting dibandingkan dengan balita yang lahir dari ibu yang hamil di usia normal. Hasil dari analisis tersebut dapat dinyatakan bahwa usia ibu saat pertama hamil merupakan faktor resiko terhadap kejadian stunting pada balita.

Usia ibu hamil (maternal age) sebaiknya tidak terlalu muda dan tidak terlalu tua. Usia yang kurang dari 20 tahun atau lebih dari 35 tahun, beresiko tinggi untuk melahirkan. Manuaba mencatat bahwa kehamilan di bawah usia 20 tahun akan beresiko mengalami anemia, gangguan tumbuh kembang janin, keguguran, prematuritas, atau BBLR, gangguan persalinan, preeklampsi, perdarahan antepartum $^{14}$. Usia ibu saat melahirkan merupakan salah satu faktor penyebab kematian perinatal. Dalam kurun waktu reproduksi sehat dikatehui bahwa usia aman untuk persalinan adalah $20-35$ tahun. Jika dilihat dari tabel 2 dapat diketahui bahwa usia ibu saat pertama kali hamil merupakan usia rawan atau tidak dianjurkan karena sebagian besar usia hamil pertama ibu berada di bawah 20 tahun.

Hal ini sejalan dengan penelitian yang dilakukan Indrasari yang menyatakan bahwa ibu dengan usia beresiko (kurang dari 20 tahun) mempunyai resiko 4,2 kali lebih besar 
Tabel 2. Usia Ibu Pertama Hamil dan Kejadian Stunting pada Balita ( $\mathrm{n}=58$ balita)

\begin{tabular}{|c|c|c|c|c|c|c|}
\hline \multirow{2}{*}{$\begin{array}{l}\text { Usia Ibu Pertama } \\
\text { Hamil }\end{array}$} & \multicolumn{2}{|c|}{ Kasus } & \multicolumn{2}{|c|}{ Kontrol } & \multirow{2}{*}{$\begin{array}{c}\text { OR } \\
(95 \%) \mathrm{Cl}\end{array}$} & \multirow[t]{2}{*}{$P$} \\
\hline & $n$ & $\%$ & $n$ & $\%$ & & \\
\hline Usia Remaja & 13 & 41,4 & 7 & 20,7 & & \\
\hline Usia Normal & 16 & 58,6 & 22 & 79,3 & 3,86 & 0,016 \\
\hline Total & 29 & 100 & 29 & 100 & & \\
\hline
\end{tabular}

untuk terjadi berat badan lahir rendah (BBLR) dibanding ibu yang tidak mempunyai usia beresiko. Kejadian berat bayi lahir rendah dan kelahiran premature pada kehamilan remaja sering dikaitkan sebagai manifestasi Intra Uterine Growth Retrcition (IUGR) yang disebabkan oleh belum matangnya organ reproduksi dan status gizi ibu sebelum masa kehamilan. Kehamilan pada usia muda merupakan faktor resiko yang disebabkan belum matangnya organ reproduksi untuk hamil (endometrium belum sempurna) ${ }^{15}$.

Pada ibu yang mengalami kehamilan di usia muda mekanisme secara biologis yang berhubungan dengan kelahiran premature adalah pasokan darah ke servix dan uterus belum sepenuhnya berkembang dengan baik pada beberapa remaja yang menyebabkan aliran nutrisi pada janin saat hamil juga tidak baik. Rendahnya aliran darah pada organ genital dapat memperbesar resiko infeksi pada organ genital yang juga dapat menyebabkan kelahiran premature. Sebagaimana diketahui bahwa kelahiran premature merupakan salah satu faktor yang memperbesar terjadinya stunting pada balita ${ }^{16}$.

Ibu yang Hamil di usia remaja juga masih dalam masa pertumbuhan sehinggaapat terjadi perebutan zat gizi antara janin dan metabolism ibu itu sendiri. Keadaan tersebut akan semakin parah jika asupan zat gizi ibu tidak adekuat sehingga janin akan mengalami growth restriction sehingga mengingkatkan resiko janin lahir dengan berat badan lahir rendah atau kelahiran premature dimana kedua hal tersebut menjadi faktor terjadinya stunting pada balita ${ }^{17}$. Kehamilan di usia awal remaja, ketika ibu juga masih tumbuh akan meningkatkan resiko bayi yang dilahirkan akan menjadi stunting.

Dari tabel 3 dapat diketahui bahwa pemberian ASI eksklusif pada kelompok balita kasus (balita stunting) tidak ada yang mendapatkan ASI secara eksklusif atau $0 \%$.
Pada kelompok balita kontrol (balita non stunting) terdapat 16 balita yang mendapatkan ASI secara eksklusif atau mencapai 55,2\% dan tidak mendapatkan ASI secara eksklusif sebesar 13 balita atau mencapai 44,8\%. Rendahnya ASI eksklusif pada kelompok kasus dikarenakan terdapat perilaku - perilaku ibu yang memberikan makanan dan minuman selain ASI sebelum anak berusia enam bulan. Pada tabel 3 dapat diketahui bahwa pada kelompok balita kontrol yang mendapat ASI eksklusif lebih besar dibandingkan dengan kelompok balita kasus.

Hasil analisis Chi - square menyatakan bahwa terdapat hubungan yang signifikan antara riwayat pemberian ASI eksklusif dengan kejadian stunting pada balita dengan nilai $p-$ value $=0,000(p<0,05)$. Pada interval kepercayaan $(\mathrm{Cl}) 95 \%$, nilai Odds Ratio (OR) yang dihitung $(3,23)$. Nilai Odds Ratio menunjukan bahwa balita yang tidak mendapatkan ASI secara eksklusif beresiko 3,23 lebih besar mengalami stunting dibandingkan dengan balita yang mendapatkan ASI secara eksklusif. Hasil dari analisis tersebut dapat dinyatakan bahwa pemberian ASI merupakan faktor resiko terhadap kejadian stunting pada balita.

Hal ini sejalan dengan penelitian Purba yang menyatakan bahwa bayi yang tidak diberi ASI eksklusif memiliki resiko 2 kali lebih besar untuk mengalami stunting pada usia $6-12$ bulan dibandingkan dengan balita yang mendapat ASI eksklusif. Proporsi anak balita yang mengalami stunting sebesar $75,0 \%$ karena pemberian ASI yang tidak eksklusif, sedangkan proporsi anak balita yang keadaan gizinya normal sebesar 58,3\% karena pemberian ASI yang eksklusif. Dengan nilai OR 4,2 anak balita yang mengalami stunting resikonya empat kali lebih besar dibandingkan dengan yang mendapat ASI eksklusif ${ }^{[25]}$. Balita harus menyusu sampai usia dua tahun sesuai 
Tabel 3. Riwayat Pemberian ASI dan Kejadian Stunting pada Balita ( $\mathrm{n}=58$ balita)

\begin{tabular}{|c|c|c|c|c|c|c|}
\hline \multirow{2}{*}{$\begin{array}{l}\text { Riwayat } \\
\text { Pemberian ASI }\end{array}$} & \multicolumn{2}{|c|}{ Kasus } & \multicolumn{2}{|c|}{ Kontrol } & \multirow{2}{*}{$\begin{array}{c}\text { OR } \\
(95 \%) \mathrm{Cl}\end{array}$} & \multirow[t]{2}{*}{$P$} \\
\hline & $n$ & $\%$ & $n$ & $\%$ & & \\
\hline Eksklusif & 4 & 13,8 & 16 & 55,2 & & \\
\hline Non eksklusif & 25 & 86,2 & 13 & 44,8 & 3,23 & 0,003 \\
\hline Total & 29 & 100 & 29 & 100 & & \\
\hline
\end{tabular}

dengan rekomendasi WHO. Hal ini dikarenakan ASI telah terbukti memiliki efek positif terhadap daya tahan tubuh balita dan menurunkan resiko kejadian stunting pada balita. Pada penelitian ini ditemukan bahwa sakit yang terjadi pada anak memiliki hubungan yang signifikan terhadap kejadian stunting. Balita yang pernah mengalami sakit beresiko 2,1 kali lebih besar mengalami stunting ${ }^{18}$

Memberikan ASI eksklusif adalah tidak memberi bayi makanan atau minuma lain, termasuk air putih, selain menyusui (kecuali obat - obatan dan vitamin atau mineral tetes; ASI perah juga diperbolehkan) ${ }^{19}$. Makanan pertama dan utama bayi adalah air susu ibu. Air susu ibu sesuai dengan kebutuhan bayi dalam segala hal. Karbohidrat dalam ASI berupa laktosa, yang kandungan lemaknya berupa polyunsaturated fatty acid (asam lemak tak jenuh ganda). Protein utamanya adalah lactalbumin yang mudah dicerna dan kandungan vitamin dan mineral yang tinggi. Selain itu ASI juga mengandung zat anti infeksi. Pemberian ASI eksklusif sangat penting bagi bayi sebelum bayi mendapatkan makanan lain $^{20}$. Promosi pemberian ASI eksklusif selama enam bulan dan dilanjutkan dengan pemberian makanan pendamping serta tetap memberikan ASI merupakan outline program UNICEF. Hal ini penting sebagai upaya pencegahan kejadian overweight dan stunting pada bayi dan balita ${ }^{21}$. Penelitian pada balita usia $0-6$ bulan dan rata - rata kehamilan dini adalah 19 tahun ditemukan bahwa kelompok balita yang tidak mendapat ASI eksklusif memiliki nilai HAZ (Height for Age) lebih rendah secara signifikan dibandingkan dengan kelompok balita yang mendapat ASI eksklusif. Jika dilihat pada tabel 3 bahwa pada kelompok kasus semua tidak mendapatkan ASI secara ekslusif hal tersebut yang kemudian menjadi faktor kuat terjadinya stunting pada balita.
Kandungan ASI sangat dibutuhkan dalam proses pertumbuhan balita untuk mencegah stunting, kandungan ini sering disebut dengan growth factors. Growth factors yang terdapat dalam ASI terdapat dalam jumlah banyak serta memiliki fungsi yang berbeda - beda. Pada penelitian Ballard \& Ardythe (2013) dijelaskan bahwa terdapat beberapa growth factors yang terdapat dalam ASI. Intestinal maturation, and repair : Epidermal growth factor (EGF) yang ditemukan pula pada cairan amnion. EGF berfungsi untuk mengaktivasi mekanisme proteksi pada sel usus bayi dengan cara menghambat kematian sel dan menghasilkan pro - inflammatory TNF - $\alpha$. Selain itu ASI memiliki growth - regulating hormones yaitu calcitonin dan somatostatin. Kedua hormone tersebut berfungsi untuk melindungi kandungan bioaktif pada ASI agar tidak rusak saat berada di lumen. ASI juga memiliki fungsi regulasi metabolisme dan komposisi tubuh dengan kandungan hormone adiponectin. Hormone ini memiliki fungsi yang beragam salah satunya adalah regulasi metabolism dan supresor inflamasi. Jumlah adiponektin pada ASI berhubungan dengan berat badan bayi dan BMI selama pemberian ASI eksklusif. Di samping memiliki growth factors ASI juga memiliki manfaat perlindungan terhadap infeksi. ASI memiliki kandungan slgA yang berfungsi sebagai predominant antibodi, selain itu dalam ASI juga ditemukan IgM dan IgG. Selain itu pada ASI yang dikeluarkan ibu saat awal kelahiran atau disebut colostrum juga memiliki kandungan IgA, IgM dan IgG yang juga sangat tinggi. Kandungan lain dari ASI yang berfungsi sebagai antibodi adalah lactoferrin yaitu iron - binding glycoprotein yang termasuk dalam kelompok transferrin. Senyawa ini memiliki manfaat untuk melawan bakteri, virus dan jamur. Glikoprotein lain yang berfungsi sebagai antibodi adalah lactadherin yang terdapat pada lemak susu. Lactadherin 
berpindah dari ASI menuju perut bayi dan mencegah infeksi oleh rotaviral pada bayi yang baru lahir ${ }^{22}$.

\section{KESIMPULAN}

Berdasarkan temuan statistik di atas, maka kemudian ditemukan hubungan antara usia ibu pertama hamil dan riwayat pemberian ASI dengan kejadian stunting pada balita di wilayah kerja Puskesmas Pujon Kabupaten Malang ( $p$-value 0,016; $p$-value 0,003). Balita yang lahir dari ibu yang hamil pada usia remaja 3,86 kali lebih beresiko mengalami stunting dibandingkan dengan balita yang lahir dari ibu yang menikah di usia normal. Balita yang tidak mendapatkan ASI secara eksklusif 3,23 kali lebih beresiko mengalami stunting dibadningkan dengan balita yang mendapat ASI secara eksklusif. Sehingga usia ibu pertama kali hamil dan riwayat pemberian ASI menjadi faktor resiko pada kejadian balita stunting.

Kepada praktisi kesehatan diharapkan memberikan edukasi tentang usia yang tepat untuk menikah pada remaja serta memberikan motivasi agar dapat menempuh pendidikan yang lebih tinggi. Hal tersebut diharapkan dapat menurunkan angka pernikahan di usia remaja. Selain itu praktisi kesehatan diharapkan memberikan edukasi tentang pemberian ASI eksklusif dengan harapan ibu balita mengerti konsep dan praktek tentang ASI eksklusif serta pemberian motivasi pada ibu untuk menyusui anaknya selama enam bulan penuh dan dilanjutkan hingga balita berusia dua tahun.

\section{ACKNOWLEDGEMENT}

Seluruh responden yang terlah bersedia membantu penelitian ini, Dosen Pembimbing dan seluruh dosen Ilmu Gizi Fakultas Kesehatan Masyarakat Universitas Airlangga Surabaya, Kepala Puskesmas dan Ahli gizi Puskesmas Pujon Kabupaten Malang, bidan desa dan kader posyandu, teman - teman sejawat yang banyak membantu dalam proses pengambilan data.

\section{REFERENSI}

1. WHO. Global Nutrition Targets 2025 : Stunting Policy Brief. (2012).
2. Dewey, K. G. \& Adu-afarwuah, S. Review Article Systematic review of the efficacy and effectiveness of complementary feeding interventions in developing countries. 24-85 (2008).

3. Dinas Kesehatan Provinsi Jawa Timur. Profil Kesehatan Provinsi Jawa Timur 2015. 60 (2015).

4. Astre Primadita. Laporan Pre - Dietetic Internship Rotasi Community (Pelaksanaan Kegiatan NCP Komunitas pada Kelompok Sasaran Balita) di Puskesmas Pujon Kabupaten Malang. (2017).

5. Kabupaten Malang Layak Anak 50. 5054 (2012).

6. Dinas Kesehatan Kabupaten Malang. Profil Kesehatan Kabupaten Malang Tahun 2015. (2015).

7. Vivatkusol, Y., Thavaramara, T. \& Phaloprakarn, C. Inappropriate gestational weight gain among teenage pregnancies: Prevalence and pregnancy outcomes. Int. J. Womens. Health 9, 347-352 (2017).

8. Of, O. Determinants of Children's Nutritional Status in Kenya: Evidence from Demographic and Health Surveys Jane Kabubo-Mariara. (2008). doi:10.1093/jae/ejn024

9. Kuchenbecker, J. et al. Exclusive breastfeeding and its effect on growth of Malawian infants: results from a crosssectional study. Paediatr. Int. Child Health 35, 14-23 (2015).

10. Percut, K. \& Tuan, S. E. I. No Title. 1-12

11. Desiyanti, I. W. Faktor-Faktor yang Berhubungan Terhadap Pernikahan Dini Pada Pasangan Usia Subur di Kecamatan Mapanget Kota Manado Factors Associated With Early Mariage In Couples Of Childbearing Age At Kecamatan Mapanget Manado City. 270-280

12. Langkat, S. K., Factors, T., Cause, T., Young, T. \& Of, A. Faktor-Faktor Penyebab Terjadinya Pernikahan Usia Muda Studi Kasus di Kelurahan Sawit Seberang Kecamatan Sawit The Factors That Cause The Young Age Of Marriage.

13. Correlational Analysis Between Teenage Pregnancy AND. 1-10 (2015). 
14. Puskesmas, D. I., Kulon, S. \& Yogyakarta, P. D. I. Gizi indonesia. 41, 39-48 (2018).

15. Bblr, R. \& Indrasari, N. Faktor resiko pada kejadian berat badan lahir rendah (bblr). VIII, 114-123 (2012).

16. Sharma, M. \& Mishra, P. S. Maternal risk factors and consequences of low birth weight in Infants. IOSR J. Humanit. Soc. Sci. 13, 39-45 (2013).

17. Prendergast, A. J. \& Humphrey, J. H. The stunting syndrome in developing countries. Paediatr. Int. Child Health 34, 250-265 (2014).

18. Rambitan, W. et al. Hubungan Antara Riwayat Pemberian ASI Eksklusif dengan Kejadian Stunting pada Anak Batita di
Wilayah Kerja Puskesmas Kawangkoan Kabupaten Minahasa. 167, (2014).

19. infodatin. Analisis dan Situasi ASI. (2014).

20. Arisman, Dr., M. Gizi dalam Daur Kehidupan. (Penerbit Buku Kedokteran EGC, 2008).

21. who. Guidelines for Preventing Early Pregnancy and Poor Reproductive Outcome in Adolescents in Developing Countries. (2011).

22. L.Morrow, O. B. \& A. Human Milk Composition: Nutrients and Bioactive Factors. J. Natl. Inst. Heal. 60, (2013). 